\title{
Up-Cycle Of Plastic Opp Laminate; From Waste Into Handicraft Products Raw Material
}

\author{
Ratna Endah Santoso \\ Textile Art Work Program \\ Faculty of Fine Arts and Designs (FSRD) \\ Universitas Sebelas Maret (UNS) Surakarta, Indonesia
}

\author{
Nidyah Widyamurti \\ Three Year Diploma Program of Visual Communication \\ Designs \\ Faculty of Fine Arts and Designs (FSRD) \\ Universitas Sebelas Maret (UNS) Surakarta, Indonesia \\ *Corresponding author: nidyah1234567890@gmail.com
}

\begin{abstract}
In the current digital era, the development of printing industry is still irreplaceable. Printing products in the forms of books, packaging, and the likes are still actively produced today. However, the printing industry is one of the waste producers that are quite detrimental to the environment because it produces waste materials and harmful substances such as plastic. Although there have been several technologies in printing waste processing, not all printing industries have implemented them, so the impact on environmental damage due to printing industry waste keeps happenning. The initial stage of this research was carried out on OPP (oriented polypropylene) plastic laminate. OPP plastic is usually used in the finishing process in the production of book covers, packaging, invitations, and others. In some printing industries, OPP plastic production residual lamination is still only thrown away. This initial research is an upcycle program for OPP Laminated plastic waste into a rope as raw material for handicraft products with economic value. The final result of this study is a rope processed by OPP plastic Laminates which is ready to be used as raw material for handicraft products. The results showed that the OPP plastic Laminate rope met the expected quality standards as raw material for handicraft products. The research findings recommend that OPP Lamination rope to be used as an alternative raw material for the development of handicraft products. The handicraft product using the OPP Lamination plastic strap will be the next phase of the research project.
\end{abstract}

Keywords : upcycle of printing industry waste, OPP Plastic Laminates, plastic rope

\section{INTRODUCTION}

Plastic waste is a problem that has been considered as a serious threat of environmental pollution, especially for soil pollution. Plastic material is a material that cannot be decomposed by bacteria, so it cannot be destroyed even though it has been buried in the soil for years and it will remain in its original form. Even plastic waste will not burn to ash.

OPP Plastic laminate is one type of plastic commonly used as lamination in the process of printing finishing on paper. According to Hasta Nurulita (2017) in a seminar paper on Corona Treatment System in BOPP Film, BOPP (or OPP) is a film plastic that is widely used for plastic packaging purposes in the food and beverage, pharmaceutical, cigarette, detergent, shampoo, garment, cosmetics industries etc. This BOPP film is made of polypropylene resin and other synthetic chemicals so that BOPP plastic is one of the materials that are difficult to decompose naturally.

The amount of waste from OPP plastic laminate produced from printing is quite a lot per day. Each production process of books or product packagings, for example, produces an average waste width of 1 to $20 \mathrm{~cm}$ along 3,000 meters of OPP plastic laminate. Meanwhile, the printing company has not implemented a recycling system to overcome it to date, and in the end OPP plastic laminate waste is only accumulated into garbage. For this reason, it is necessary to create creative ideas to use them into products with economic value.

This research resulted products made from OPP plastic laminate waste in the form of ropes that can be used as fashion materials, interior decoration, and many other handicraft products. Through simple yarn spinning technology which is a tool called erek, OPP plastic Laminate waste can be converted into a rope that can be of economic value.

So far, most handicraft raw materials come from natural fibers, such as: bark, leaves, cotton, wool, and others. There are also synthetic fibers available that are commonly produced by chemical processes that have a very bad impact on nature and the environment. OPP plastic laminate waste treatment is expected to be a solution for the abundance of OPP plastic laminate waste in the printing industry. The resulted rope also has a unique and distinctive texture, so that it can be applied in various interior elements, product design, craft, even fashion.

\section{LITERATURE REVIEW}

\section{A. OPP Plastic Laminate}

Javeriya (2013) in the International Research Journal of Environment Sciences explained that Polypropylene (PP) has the characteristics of low density, excellent chemical resistance, environmental stress resistance, high melting points, good process abilities, dielectric properties, low cost, and creep resistance. This is in line with Francesco's (2002: 8) understanding, that PP as the second most common linear thermoplastic of the polyolefin family, PP has a lower impact strength, but superior working temperature and tensile strength. PP has excellent insulating properties, its insoluble at room temperature, but dissolves in hydrocarbons and chlorinated hydrocarbons above 80 0C. Of all the major plastic, PP is the lightest, 
has excellent resistance to organic solvents, and has good heat and creep resistance.

In its product specifications, D \& K Group, Inc. a plastic distributor company in Jakarta, explained that polypropylene is a semi thermal plastic crystalline which has a high impact resistance and mechanical properties of strength and toughness, and widely used in the industrial sector, and also one of the usual common polymer materials. Australian coins also use polypropylene production. BOPP referred to as OPP.

Table 1. Type of OPP Plastic Size provided by the distributor Source: D \& K Group, Inc.

\begin{tabular}{|r|c|c|}
\hline Thickness & $\begin{array}{c}\text { Available Configurations } \\
\text { (Film Thickness } \\
\text { Mils/Adhesive } \\
\text { Thickness Mils) }\end{array}$ & $\begin{array}{c}\text { Available } \\
\text { Finishes }\end{array}$ \\
\hline $\begin{array}{c}\text { Light } \\
\text { (LIT) }\end{array}$ & 1.3 mils & Gloss, Matte \\
\hline $\begin{array}{r}\text { Standard } \\
\text { (STD) }\end{array}$ & 1.5 mils (.5/1) & $\begin{array}{c}\text { Gloss, Matte, } \\
\text { Scuff } \\
\text { Resistant Matte }\end{array}$ \\
\hline 3 mil & $5 / 2.5$ & Gloss \\
\hline 5 mil & $1 / 4$ & Gloss \\
\hline
\end{tabular}

Catherine (2016), a marketing company from a plastic company, described the product as follows: Polypropylene (OPP) lamination films offers a clear and bright finishing for a variety of applications. OPP is a soft film that folds easily and features inherently dry erase (write-on, wipe-off) properties. A combination of good performance characteristics and low price points makes ideal OPP laminating films for applications including book covers, folders, dry erase boards and calendars, and product packaging. OPP Film Highlights: 1) Excellent optical properties (clarity), 2) Folds Well, 3) Economical, cost-effective, 4) Dry erases (write-on / wipe-off) properties, 5) Softer than Polyester (PET).

Based on the above notions, OPP Laminated plastic is in the category of plastic type Polypropylene which is available in two variants, namely glossy and doff. The properties of this plastic are clear, heat resistant and flexible. The characteristics of OPP plastic Laminate waste are elongated, clear, flexible, resistant to stretch / pull, resistant to high temperatures, resistant to acids, bases, and oils.

\section{B. Printing Industry Waste}

In the Online KBBI (Extensive Dictionary of Indonesian Language), waste is defined as: 1) the residue of the production process, 2) materials that do not have value or are not valuable for ordinary or primary purposes in making or using, and damaged or defective goods in the production process. If waste is not managed well or ignored, it will become a polution that is detrimental to the environment.
OPP plastic laminate has a quite low characteristics of WVTR (water vapor transmission rate), in whic the steam circulation limited, so it is good to maintain product quality during storage. OPP Plastic lamination is applied to printed paper products to protect them from liquid and moisture, to add to the beauty of the product, and to enhance the product strength as well as to make the product look cleaner.

The OPP material form which is available in the market is a rolled sheet with a length of about + 3,000 meters. Because there has never been an OPP plastic recycling or up-cycling process, the remaining of the lamination in the printing industry only accumulates into garbage. Not all companies run their industrial waste treatment programs in accordance with established standards, because waste management requires large costs, resources, technology, and good management.

\section{Upcycle}

Upcycle is one of the solutions to overcome environmental problems. McDonough (2013: 12) stated that the goal of the up-cycle is a delightfully diverse, safe, healthy world with clean water, water, soil, and power which can be economically, equitably, ecologically, and elegantly enjoyed.

The up-cycle process provides added value to materials that were previously labeled as waste. Through the up-cycle process, the waste produced can have economic value. Up-cycle is a method of processing waste or a useless material into a new material that is more valuable, or even economical. This is sometimes more effective and more economical than creating products from new raw materials.

The mission to improve people's understanding on natural / environmental conservation and the slow economic growth become the triggers of creative ideas about up-cycling. The term upcycling was proposed for the first time by McDonough and Braungart (2002) in their first book entitled Cradle To Cradle: Remaking The Way We Make Things which introduced ideas about the sustainability movement about the use of objects that are considered useless into new products that benefit human life.

Goldsmith (2009) stated that up-cycling refers to reusing objects in a new way without degrading the material it is made from, opposed to recycling which generally involves using energy. Up-cycling is closely related to the 'green' lifestyle phenomenon about how we reduce, reuse, or recycle waste around us.

Earley (2011) in Charlote (2016) emphasized that this "valuing the waste" mind-set is both a design practice and a political statement about creating sustainable solutions to complex social and environmental challenges. Up-cycled products and processes are not just 'better than the original, they 
also incorporate the aging process, telling stories like 'production with zero waste', 'small is beautiful' and 'starting local, but think globally'. Consequently, up-cycling is both concerned with re-assessing the past and paving the way for a desired future.

The up-cycle process is different from recycle. In recycle a new form is created by previously breaking the original material into certain material as raw material, while in up-cycle, a new form is created by changing the material form without previously going through the process of solving the original material. Creativity is needed in this process. Existing technology and equipment can be used in the processing process.

As a comparison, Adidas recycling technique is used to process plastic bottle waste into a rope that is knitted with Parley Ocean Plastic Primeknit term. One shoe requires $11 \mathrm{PP}$ plastic bottles. The plastic thread is then combined with other materials to be used as raw material for shoe products called UltraBoost Parley. Through the Run For The Oceans event held in Jakarta on June 8 - July 82018 ago, ADIDAS conducted a campaign to overcome the impact of plastic waste that pollutes the oceans (www.kompas.com).

\section{Handicraft}

Ammar (2008) in the Let's Know: Handicrafts of India book categorizes handicraft as an object made by skillful use of one's hands. Handicraft is also known as a result of productive activities that produce unique and economic value. Another feature of handicraft is the process of product work done manually with simple techniques and equipment. In his book, Ammar categorizes handicraft in three categories: folk crafts, religious crafts, and commercial crafts.

Handicraft is an important asset to support and develop a country's tourism sector. Crafts which are categorized as handicrafts are different from crafts produced in the industrial category. Fatiha (2016) argued that in traditional handicrafts relies more on manual capabilities as a result of learning process. The uniqueness and the process of creating handycraft works can make the product become more valuable, and it is not found in the industry category.

At present, in the Indonesian market, handicraft raw materials are dominated by natural fibers, wood, plastic, fabric, bamboo, and so on. The existence of OPP Lamination plastic strap is believed to be an alternative raw material for handicraft products to be made into unique products.

\section{RESEARCH METHOD}

\section{A. Research Design}

This action research in the City of Surakarta, Central Java, Indonesia was conducted in 2017 by Lecturers and Students of Textile Crafts of
Universitas Sebelas Maret (UNS) Surakarta. Being concerned with the large amount of meaningless OPP plastic laminate waste in Surakarta City, the researcers came up with the idea of processing (upcycle) it into rope as handicraft raw material with economic value.

Products that can later be produced from the Laminated OPP plastic rope are craft products, interior products, and fashion products that will be the next research project.

Diagram 1. Research Mindframe

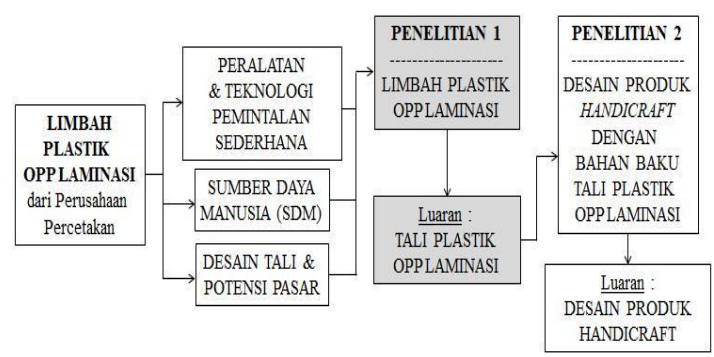

\section{B. Material and Method}

The OPP plastic Laminate waste selected in this study is the Glossy type 1-2 cm OPP plastic Laminates. Adjustments were made when there were different sizes.
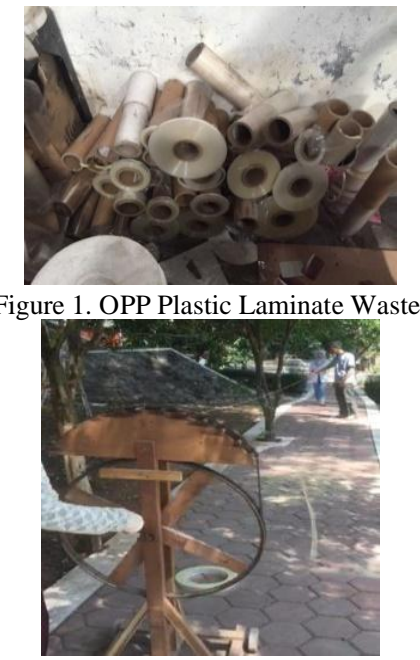

Figure 2. Simple Thread Spinning Tool called Eret

\section{RESULTS AND DISCUSSION}

\section{A. OPP Laminate Plastic Waste Processing Method into Rope}

The steps taken were very simple, namely by treating OPP plastic Laminate waste in 1-2 cm length with a roll of around 3,000 meters into a rope by cleaning and separating between the doff and glossy parts. Then the waste was grouped according to predetermined size, stretched continuously and with a stable pull, so that it can shrink, lengthen, and change shape into a rope. In the spinning process, one plastic rope is connected with the next plastic rope, so that it becomes long and ready to roll. For color rendering, the OPP plastic Laminate is combined with colored rayon yarn and spun 
together. The thread colors used were red, yellow, green, blue, purple and black.

The technology used is yarn spinning technology with yarn spinning equipment called eret, it is a simple process so that it can be done by anyone. The processing stage is described in the following scheme:

1. Selecting plastic waste

2. Cleaning

3. Stretching

4. Spinning

5. Rolling

\section{A. OPP Plastic Laminate Rope}

The result of OPP plastic Lamination waste spinning is a white rope as shown in Figure 3, while for producing colored OPP ropes, nylon yarn is inserted/combined with the plastic thread (Figure 5) in OPP plastic Laminate sheets in the spinning process.

Plastic rope products in Figures 3 and 4 are the results of the Final Projects research of Arts / Textile Department students. In the process of material selection, spinning (color rendering) and technical methods, experiments were carried out to make it easier to determine motifs, shapes and colors to find out how a motif design can be produced with makrame (weaving) techniques, and a combination of techniques, so that maximum results can be obtained. The spinning experiment was carried out to give color to the rope and to determine the density and size of the desired rope (Bagus in Ratna, 2014).
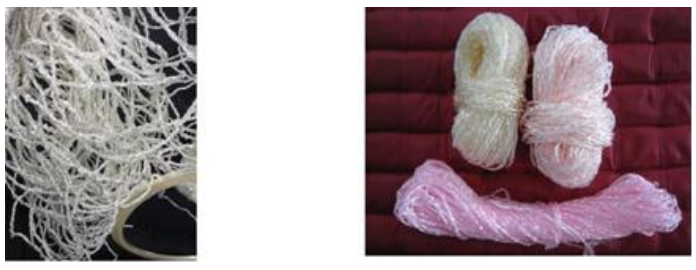

Figure 3. Rope made from OPP Plastic Laminate after spinning process

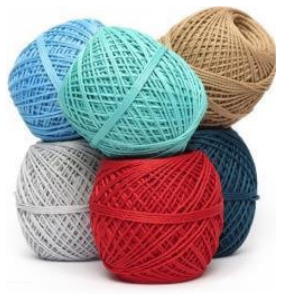

Figure 4. Rope made from combination of OPP plastic laminate and Nylon

The advantages of processing rope from OPP plastic Laminate waste are: first, through the utilization of OPP plastic Laminate waste can provide a solution to reduce printing waste. The creation of this technique can be an important instrument in the management and processing of printing waste, because it greatly affects the quality of the environment. The utilization of OPP plastic Laminate waste as a raw material for fashion, interior decoration, and many other handicraft products can provide new solutions in the world regarding industrial plastic waste processing. Second, the visual and texture of the fabric produced through this technique has its own uniqueness and aesthetic values, thus that it can be applied in a variety of fashion, interior decoration and other handicraft products.
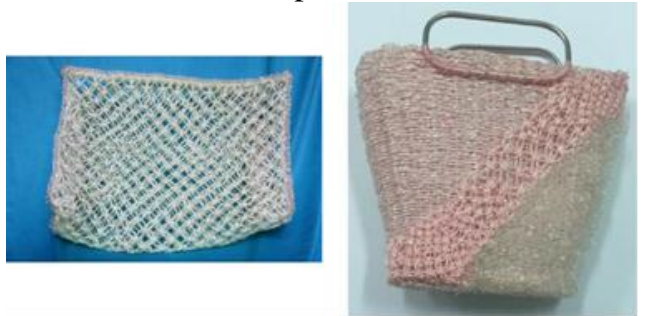

Figure 5. Samples of handicraft of Plastic Laminate rope Source: Bagus, 2014

\section{CONCLUSION}

OPP plastics Laminates as industrial waste from printing companies is very difficult to eliminate, due to the magnitude of the role of OPP plastics for product performance. Thus, it is necessary and urgent for the innovation to process OPP plastic laminate waste into products of economic value. The up-cycle process is one of the wise innovations because; 1) it brings a positive impact on the environment, 2) it will generate added value for the printing company concerned or anyone who can process it; 3) it produces alternative raw materials that will stimulate the creativity of handicraft craftsmen

The selling value of OPP Laminate plastic rope products has not been calculated for now. However, with the development of the production system and its processing technology, it can be developed into various products with selling value that can become the source of the people's economy.

\section{REFERENCES}

Journal

Ratna Endah Santoso, Tiwi Bina Affanti, Bagus Nugroho. Pemanfaatan Limbah Plastik OPP Dengan Menggunakan Teknik Tekstil Untuk Produk Tas Wanita. Tugas Akhir Jurusan Kriya Seni/Tekstil, Fakultas Seni Rupa dan Desain. Universitas Sebelas Maret Surakarta. NIM C0905005

Charlotte Wegener, Marie Aakjær. 2016. Upcycling A New Perspective On Waste In Social Innovation. Department of Communication, Aalborg University, Denmark. Journal of Comparative Social Work 2016/2. http://journal.uia.no. ISSN: 0809-9936

Fatiha Bouziane, Azizul Hassan. 2016. Strategic Determinants For The Development of Traditional Handicraft Industry Of Algeria. International Journal of Managing Value and 
Supply Chains (IJMVSC) Vol.7, No.1, March 2016. DOI: $10.5121 /$ ijmvsc.2016.7101 1

Hasta Nurlita, Ir.Agung Warsito. 2017. Makalah Seminar Kerja Praktek - Sistem Corona Treatment Untuk BOPP Film Pada PT Polydayaguna Perkasa. Fakultas Teknik. Universitas Diponegoro Semarang. 27 Pebruari 2017

Javeriya Siddiqui, Govind Pandey. 2013. A Review of Plastic Waste Management Strategies. Department of Civil Engineering, M.M.M. Engineering College, Gorakhpur-273010, UP, INDIA. International Research Journal of Environment Sciences. Vol. 2 (12), 84-88, 20 Desember 2013. ISSN 2319- 1414

\section{Buku}

Amar Tyagi. 2008. Let's Know: Handicrafts of India. ibs Books. United Kingdom. ISBN: 978-1-905863-18-1

Francesco La Mantia (Ed). 2002. Handbook of Plastics Recycling. Rapra Technology Limited. Shawbury, Shrewsbury, Shropshire, SY4 4NR. United Kingdom. ISBN : 1-85957-325-8

McDonough, William \& Braungart, Michael. 2002. Cradle to Cradle: Remaking the Way We Make Things. North Point Press. New York. ISBN: 086547-587-3

McDonough, William \& Braungart, Michael. 2013. The Upcycle: Beyond Sustainability--Designing for Abundance. North Point Press. New York. ISBN: 978-0-86547-748-3

\section{Digital}

CatherineZhang. 2016. The Difference Between PP, $O P P, \quad B O P P$ and

Identification of Three Kinds of Thin Film Materials. https://www.linkedin.com/pulse/differencebetween-pp-opp-bopp-identification-three-kindszhang. Diterbitkan tanggal 28 Pebruari 2016

D\&K Group, Inc. Base Film Types. http://www.dkgroup.com/product/ polypropyleneopp-lamination-films/

Goldsmith, Belinda. 2009. Trash or Treasure Upcycling Becomes Growing Green Trend. Sydney (Reuters). https://www.reuters.com/article. Download tanggal 20 Juni 2018

Kamus Besar Bahasa Indonesia (KBBI) Online. https://kbbi.web.id/

Melawan Sampah Dengan Berlari. Kompas.com. https://lifestyle.kompas. com/read/2018/06/23/080800120/melawansampah-plastik-dengan-berlari. Diterbitkan tanggal 23 Juni 2018

Picture

www.mayacrafts.asia 